\title{
lodine I 124-labeled Anti-PSCA A11 Minibody
}

National Cancer Institute

\section{Source}

National Cancer Institute. Iodine I 124-labeled Anti-PSCA A11 Minibody. NCI Thesaurus.

Code C114501.

A radioconjug ate composed of an affinity-matured antibody fragment, the A11 minibody, directed against human prostate stem cell antigen (PSCA), and conjug ated with the radioisotope iodine I 124, that can potentially be used as an imaging agent for positron emission tomography (PET)/computed tomography (CT). The minibody moiety of iodine I 124-labeled anti-PSCA A11 minibody selectively targets and binds to PSCA. The PSCAexpressing tumor cells can then be visualized using PET/CT. PSCA, a cell surface antigen expressed in normal human prostate and bladder, is overexpressed in a variety of cancers, including bladder, pancreatic, and prostate cancer. The A11 minibody is formed by the fusion of a single chain Fv fragment with the immunoglobulin G1 CH3 domain. 